\title{
VIABILITY AND MOLECULAR AUTHENTICATION OF Coccidioides spp. ISOLATES FROM THE INSTITUTO DE MEDICINA TROPICAL DE SÃO PAULO CULTURE COLLECTION, BRAZIL
}

\author{
Sarah Desirée Barbosa CAVALCANTI(1), Mônica Scarpelli Martinelli VIDAL(1), Maria da Glória Teixeira de SOUSA(1) \& Gilda Maria Barbaro DEL NEGRO(1)
}

\begin{abstract}
SUMMARY
Coccidioidomycosis is an emerging fungal disease in Brazil; adequate maintenance and authentication of Coccidioides isolates are essential for research into genetic diversity of the environmental organisms, as well as for understanding the human disease. Seventeen Coccidioides isolates maintained under mineral oil since 1975 in the Instituto de Medicina Tropical de São Paulo (IMTSP) culture collection, Brazil, were evaluated with respect to their viability, morphological characteristics and genetic features in order to authenticate these fungal cultures. Only five isolates were viable after almost 30 years, showing typical morphological characteristics, and sequencing analysis using Coi-F and Coi-R primers revealed 99\% identity with Coccidioides genera. These five isolates were then preserved in liquid nitrogen and sterile water, and remained viable after two years of storage under these conditions, maintaining the same features.
\end{abstract}

KEYWORDS: Culture collection; Coccidioides; Viability; Molecular identification; Long-term preservation.

\section{INTRODUCTION}

Coccidioides spp. is a dimorphic fungus that causes coccidioidomycosis, a systemic mycosis affecting humans and a wide variety of animals. The disease is acquired through inhalation of infective arthroconidia that propagates in soil where the fungus lives in the mycelial form. Coccidioidomycosis is endemic in the semi-arid regions of southwestern United States, northern Mexico, and certain areas of Central and South America. It is considered to be a re-emerging disease in the United States, as the number of cases has increased markedly over the past decade ${ }^{8}$.

Since 1978, the disease has been diagnosed in several patients in the semi-arid northeastern region of Brazil, more frequently in Piauí, Ceará, Maranhão, and Bahia states ${ }^{10,14,23,31,33}$. Studies using delayed hypersensitivity tests with coccidioidin have demonstrated the presence of healthy infected individuals in these states, which are now considered to be endemic areas in Brazil ${ }^{6,7,33}$. It is possible that the disease remains underdiagnosed and that its geographic distribution extends throughout the northeastern region of the country ${ }^{11}$.

Diagnosis of coccidioidomycosis is based on culture isolation, serology, and histopathology. The identification of the fungus requires in vitro conversion of the mycelial form into the parasitic phase and/or the use of molecular probes ${ }^{2,5,9,27}$. Because handling of Coccidioides spp. is dangerous, many researchers have developed molecular techniques to diagnose the disease. Polymerase chain reaction (PCR) assays targeting conserved or variable regions of the ribosomal DNA to detect and identify Coccidioides spp. have been described and found to be sensitive and specific $^{2,12,15,16,18,21,27,30,32}$.

Molecular phylogenetic methods based on single-nucleotide polymorphisms and microsatellite repeats have established a new species, Coccidioides posadasii, which is morphologically indistinguishable from $C$. immitis $^{12,19,30}$. Differences in the amino acid composition of various proteins between the two species suggest that other phenotypic differences may exist, including differences in factors involved in pathogenicity ${ }^{12}$

The preservation of pathogenic fungi is essential for systematics, epidemiology, pathogenesis and genetic studies. The methods used for preservation should allow high-quality, long-term storage and full recovery, as well as ensuring phenotypic and genetic integrity of the organisms ${ }^{25,26}$. Subculturing can damage isolates, resulting in a decrease in spore production and pleomorphism, in addition to increasing the risk of contamination of samples ${ }^{4,22}$. There are several other methodologies available for the preservation of fungi that present various advantages and disadvantages, depending on the fungus group in question ${ }^{4,26,29}$.

The two techniques most widely used by culture collections for long-term preservation are cryopreservation in liquid nitrogen and freezedrying, both of which maintain phenotypic and genotypic features of

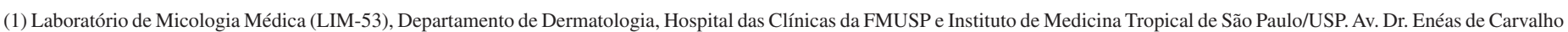
Aguiar 500, Cerqueira Cesar, 05403-000 São Paulo, SP, Brasil. Phone: 55.11.3061 7046.

Correspondence to: E-mails: sarahdbc@usp.br; movida@usp.br 
CAVALCANTI, S.D.B.; VIDAL, M.S.M.; SOUSA, M.G.T. \& DEL NEGRO, G.M.B. - Viability and molecular authentication of Coccidioides spp. isolates from the Instituto de Medicina Tropical de São Paulo culture collection, Brazil. Rev. Inst. Med. Trop. Sao Paulo, 55(1): 7-11, 2013.

the isolates and prevent contamination. However, no single method can be applied generically to all fungi. For instance, although both sterile water and mineral oil can be used for preservation of filamentous and dimorphic fungi for several years ${ }^{25}$, factors such as metabolism, age of the inoculums and quality of the mineral oil influence the ability of the fungus to survive under mineral oil ${ }^{1,20}$. However, as Coccidioides spp. pose a high risk to laboratory personnel, the organisms should be preserved under non-culturing conditions ${ }^{11,32}$.

With the implementation of biological resources centers, organisms from culture collections have been increasingly used in the development of research projects, industrial processes and training courses. It has therefore become necessary to develop better methods of preservation suitable for different demands such as the amount of fungi (e.g., industrial processing or molecular studies) and the fungus form (mold or yeast), among other purposes, ensuring purity, reproducibility and authenticity.

The aim of this study was to analyze the viability, phenotypic and genotypic features of Coccidioides spp. isolates that have been maintained under mineral oil since 1975 in the IMTSP culture collection.

\section{MATERIAL AND METHODS}

1. Coccidioides spp. isolates: The viability, morphological features and molecular characteristics of 17 isolates that were maintained in the Instituto de Medicina Tropical de São Paulo culture collection were evaluated. These isolates were originally provided by research institutions in the USA and have been preserved under mineral oil since 1975 (Table 1).

2. Fungal recovery: Fragments of the 17 Coccidioides spp. cultures maintained under mineral oil were plated on Sabouraud dextrose agar (SDA), potato dextrose agar (PDA) and tryptic soy broth (TSB), and incubated at $30{ }^{\circ} \mathrm{C}$ for up to 60 days at room temperature to evaluate fungal recovery.

3. Morphological characteristics: The cultures grown on PDA medium were evaluated for colony morphology and for microscopy of typical arthroconidia. A fragment of culture was collected and placed on a slide with one drop of lactophenol cotton blue for microscopic examination.

4. DNA isolation and sequence analysis: Fragments of the viable isolates were cultured in $50 \mathrm{~mL}$ Brain Heart Infusion (BHI) broth, in a shaking incubator at $30{ }^{\circ} \mathrm{C}$ for 48 hours. In order to minimize the risk of infection, the cultures were submitted to boiling for 20 minutes. Thereafter, samples of each isolate were plated on SDA in slant tubes and incubated at $30{ }^{\circ} \mathrm{C}$ for four weeks. Samples were considered non-viable only when no growth occurred after this time. All these procedures were performed in a safety cabinet. Two hundred milligrams of dry mycelia were submitted to freezing in liquid nitrogen, after which DNA isolation was performed using the QIAamp® DNA Mini Kit (QIAGEN, Hilden, Germany), according to the manufacturers' instructions.

Table 1

Coccidioides isolates preserved under mineral oil in the IMTSP culture collection since 1975

\begin{tabular}{|c|c|c|c|c|c|}
\hline Isolate Number & Isolation year & Origin & $\begin{array}{c}\text { Year of preservation } \\
\text { under mineral oil }\end{array}$ & $\begin{array}{l}\text { Molecular Identification } \\
\text { (sequencing) }\end{array}$ & Viability \\
\hline IMTSP Ci26 & $*$ & USA & 1980 & - & Not viable \\
\hline IMTSP Ci28 & $*$ & USA & 1980 & - & Not viable \\
\hline IMTSP Ci29 & $*$ & $*$ & 1975 & - & Not viable \\
\hline IMTSP Ci213 & 1930 & USA & 1980 & - & Not viable \\
\hline IMTSP Ci248 & $*$ & $*$ & $*$ & - & Not viable \\
\hline IMTSP Ci249 & 1930 & USA & 1979 & - & Not viable \\
\hline IMTSP Ci251 & 1963 & Guatemala & 1975 & - & Not viable \\
\hline IMTSP Ci252 & $*$ & USA & 1980 & C. immitis & Viable \\
\hline IMTSP Ci268 & $*$ & $*$ & $*$ & - & Not viable \\
\hline IMTSP Ci332 & $*$ & $*$ & $*$ & - & Not viable \\
\hline IMTSP Ci334 & $*$ & $*$ & 1976 & - & Not viable \\
\hline IMTSP Ci342 & 1930 & $*$ & 1980 & - & Not viable \\
\hline IMTSP Ci397 & $*$ & $*$ & 1982 & - & Not viable \\
\hline IMTSP Ci485 & 1958 & USA & 1979 & C. immitis & Viable \\
\hline IMTSP Ci510 & 1945 & USA & 1980 & C. immitis & Viable \\
\hline IMTSP Ci520 & 1945 & USA & 1978 & C. posadasii & Viable \\
\hline IMTSP Ci604 & 1939 & USA & 1980 & C. posadasii & Viable \\
\hline
\end{tabular}

*unknown 


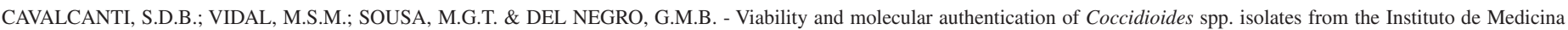
Tropical de São Paulo culture collection, Brazil. Rev. Inst. Med. Trop. Sao Paulo, 55(1): 7-11, 2013.

DNA samples were first submitted to PCR amplification with ITS1 and ITS4 primers $^{13}$ in order to verify DNA integrity and the absence of amplification inhibitors. Once this had been established, $10 \mathrm{ng}$ of the DNA samples were used as a template in PCR assays employing Coccidioidesspecific primers CoiF (5'-TACGGTGTAATCCCGATACA-3') and CoiR (5'-GGTCTGAATGATCTGACGCA-3') to amplify a 720-bp amplicon of $C$. immitis, as previously described by UMEYAMA et al. (2006). Amplifications were performed in $25 \mu \mathrm{L}$ reaction volumes consisting of 2.5 U Platinum Taq polymerase (Invitrogen, Brazil), $1.5 \mathrm{mM} \mathrm{MgCl}$, $200 \mu \mathrm{M}$ deoxynucleotide triphosphates (Invitrogen) and $10 \mathrm{pmol}$ of each primer in $1 \times$ enzyme buffer (Invitrogen). Reaction mixtures were submitted to the following conditions: one cycle at $94{ }^{\circ} \mathrm{C}$ for three minutes, followed by 35 cycles at $94{ }^{\circ} \mathrm{C}$ for $30 \mathrm{~s}, 60{ }^{\circ} \mathrm{C}$ for $30 \mathrm{~s}$, and $72{ }^{\circ} \mathrm{C}$ for $45 \mathrm{~s}$, and a final extension step at $72{ }^{\circ} \mathrm{C}$ for seven minutes.

Two microliters of each PCR product were submitted to electrophoresis in $2 \%$ ethidium bromide-stained agarose gels and visualized in a photodocumentation system (Vilber Lourmat, France). The ITS amplified products were purified using the PureLink ${ }^{\mathrm{TM}}$ PCR purification kit (Invitrogen), and sequenced in both forward and reverse directions using an ABI PRISM 3100 automated DNA sequencer (Applied Biosystems, USA). The sequences obtained were edited and aligned by means of the BLAST program (GenBank Database).

5. Preservation of isolates in sterile water and liquid nitrogen: Samples of the viable and authenticated $C$. immitis and $C$. posadasii isolates were then maintained in sterile water and liquid nitrogen for further viability evaluation. For this purpose, fragments of cultures grown on the PDA medium were collected and transferred to vials containing 5 $\mathrm{mL}$ of sterile water and stored at $4{ }^{\circ} \mathrm{C}$, while other fragments were placed in cryovials containing glycerol as the cryoprotectant and maintained in the vapor phase in liquid nitrogen storage tanks. After two years of maintenance under these conditions, the organisms were cultured in PDA again to assess recovery.

\section{RESULTS}

Only five of the 17 isolates maintained under mineral oil for almost 30 years in the IMTSP culture collection were viable after 60 days of incubation in the three media employed for this purpose. These five isolates of Coccidioides spp. were also all recovered after two years of storage in liquid nitrogen and sterile water, and the morphological characteristics of the genera were retained. These isolates presented typical morphological characteristics of Coccidioides such as white velvety colonies, hyaline and septate hyphae, although only two isolates (Ci252 and $\mathrm{Ci} 485)$ revealed typical arthroconidia. These methods employed therefore increase the chances of retaining viability and morphological and genetic stability, and can be applied to long-term preservation of dimorphic fungi $i^{4,17,24}$.

The results of PCR employing the Coccidioides-specific primers (CoiF and CoiR) revealed that two of the five Coccidioides isolates (Ci520 and Ci604) were C. posadasii species. The amplified product from this species is shorter than that from $C$. immitis, revealing a deletion of nucleotides in the corresponding sequence (Fig. 1). Our results corresponded to the findings of UMEYAMA et al. (2006), who had demonstrated that these primers could distinguish the two Coccidioides species by comparison of the amplicon sizes on agarose gels.

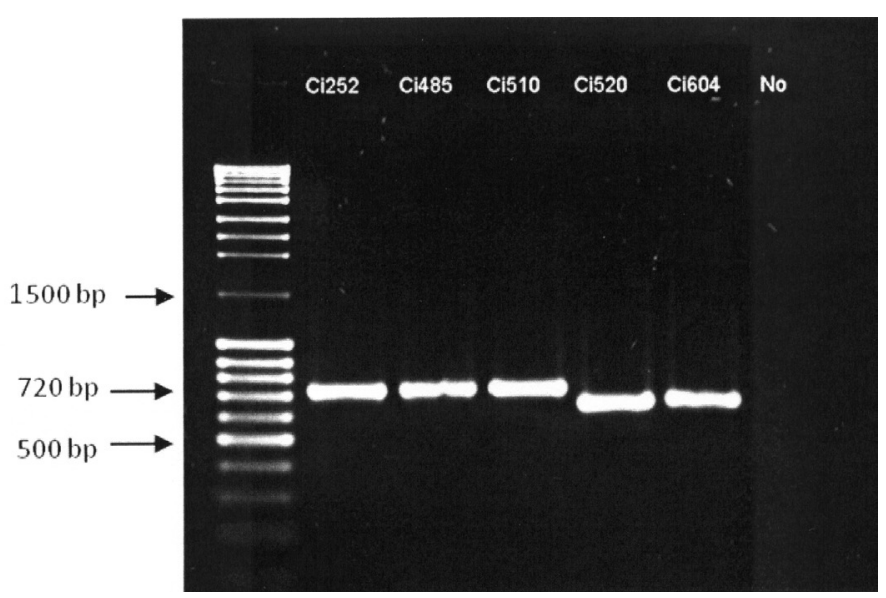

Fig. 1 - Agarose gel (2\%) showing PCR products after amplification with CoiF and CoiR primers (UMEYAMA et al., 2006). Ci252/Ci485/Ci510 correspond to C. immitis (720 bp), and Ci520/Ci604 correspond to C. posadasii. No: negative control. MW: 100 bp molecular weight marker (MassRuler DNA ladder, Fermentas, USA). The amplified product is smaller in $C$. posadasii than in C. immitis, reflecting deletion in the corresponding DNA sequence.

The DNA sequences of the amplicons obtained with the ITS primers were compared with the Coccidioides reference strain sequences available in GenBank. Two isolates (Ci520 and Ci604) showed 99-100\% identity with $C$. posadasii (accession number AB2329900) and the other three isolates (Ci252, Ci435 and Ci510) showed 99\% identity with C. immitis sequences (accession number AB232890).

\section{DISCUSSION}

Since coccidioidomycosis is an emerging fungal disease in Brazil, the adequate maintenance and authentication of Coccidioides isolates are essential for research into genetic diversity of the environmental organisms, as well as for understanding the human disease. We showed that of the 17 isolates kept under mineral oil for almost 30 years at the IMTSP culture collection, only five remained viable. The low viability of the isolates may be related to the preservation and storage conditions. The mineral oil method is based on the reduction of the metabolic rate of the microorganism due to decreased oxygen consumption, which possibly affects conidiogenesis and viability, especially in fungi such as dimorphic fungi which have stringent metabolism ${ }^{1}$. High rates of viability using this preservation method have mainly been reported for filamentous fungi; this is probably because dimorphic fungi are more susceptible to the accumulation of toxic metabolites that may occur during the process of metabolic rate reduction, causing a decrease in viable fungus recovery ${ }^{22}$. In addition, the protracted period of almost 30 years for which the isolates remained under mineral oil may have affected the survival of the fungi ${ }^{3}$. Additionally, other factors such as the quality of the mineral oil and variability in the storage temperature may have affected the survival rates, as has previously been observed by other authors ${ }^{20,28}$. In addition, while storage in liquid nitrogen is a well-established storage method for many fungi, no single method should be used for preservation as some methods are not adequate for all organisms. Accordingly, international guidelines recommend that a second method should be used, along with multiple sampling for each isolate ${ }^{34}$.

Safe extraction procedures are essential when handling cultures of 
CAVALCANTI, S.D.B.; VIDAL, M.S.M.; SOUSA, M.G.T. \& DEL NEGRO, G.M.B. - Viability and molecular authentication of Coccidioides spp. isolates from the Instituto de Medicina Tropical de São Paulo culture collection, Brazil. Rev. Inst. Med. Trop. Sao Paulo, 55(1): 7-11, 2013.

hazardous fungal pathogens. The inactivation of Coccidioides cultures by heat was required to minimize the risk of infection; boiling the cultures was effective for inhibiting growth while not affecting the quality of the extracted DNA ${ }^{15}$. The use of PCR assays for identification of Coccidioides reduces the time for analysis, decreases manipulation of hazardous material and provides reliable data, enabling authentication of the isolates ${ }^{2}$.

Molecular approaches have revealed many fungal species that were previously unknown. However, in addition to the genotypic analysis, species identification should include a description of the morphological features, physiological characteristics and biochemical features, thereby building up the polyphasic taxonomy and ensuring the authenticity of the microorganisms maintained in culture collections, and in this way reliably providing verified organisms for research.

\section{RESUMO}

\section{Viabilidade e autenticação molecular de isolados de Coccidioides spp. da coleção de culturas do Instituto de Medicina Tropical de São Paulo, Brasil}

Coccidioidomicose é uma doença emergente no Brasil; a manutenção adequada e autenticação de isolados de Coccidioides spp são essenciais para a pesquisa em diversidade genética de micro-organismos, bem como para a compreensão da doença em humanos. Dezessete isolados de Coccidioides preservados em óleo mineral desde 1975 na coleção de culturas do Instituto de Medicina Tropical de São Paulo (IMTSP) foram avaliados com relação à viabilidade, características morfológicas e genéticas, com o objetivo de autenticação das culturas fúngicas. Dos 17 isolados, apenas cinco foram viáveis após quase 30 anos mantidos em óleo mineral, apresentando características morfológicas e moleculares típicas do gênero, o sequenciamento utilizando os oligonucleotídeos Coi-F e Coi- $\mathrm{R}$ revelou identidade de $99 \%$ com isolados de Coccidioides. Estes cinco isolados foram preservados em nitrogênio líquido e água destilada esterilizada, e permaneceram viáveis após dois anos de armazenamento sob estas condições, mantendo as mesmas características.

\section{ACKNOWLEDGMENTS}

This work was supported by FAPESP (Process: 2007/55958-3)

\section{CONFLICTS OF INTEREST}

The authors report no conflicts of interest. The authors alone are responsible for the content and writing of the paper.

\section{REFERENCES}

1. Bezerra CCF, Lima RF, Lazera MS, Wanke B, Borba CM. Viability and molecular authentication of Coccidioides immitis strains from culture collection of the Instituto Oswaldo Cruz, Rio de Janeiro, Brazil. Rev Soc Bras Med Trop. 2006;39:241-4.

2. Bialek R, Kern J, Hermann T, Tjerina R, Ceceñas L, Reischl U, et al. PCR assays for identification of Coccidioides posadasii based on the nucleotide sequence of the antigen 2 proline-rich antigen. J Clin Microbiol. 2004;42:778-83.

3. Borba C, Rodrigues KF. Viability and sporulating capability of Coelomycetes preserved under a range of different storage regimes. Rev Iberoam Micol. 2000;17:142-5.
4. Borman AM, Szekely A, Campbell CK, Johnson EM. Evaluation of the viability of pathogenic filamentous fungi after prolonged storage in sterile water and review of recent published studies on storage methods. Mycopathologia. 2006;161:361-8.

5. Cole GT, Kruse D, Seshan KR. Antigen complex of Coccidioides immitis which elicits a precipitin antibody response in patients. Infect Immun. 1991;59:2434-46.

6. Cordeiro RA, Brilhante RSN, Rocha MFG, Bandeira SP, Fecchine MAB, Camargo ZP, et al. Twelve years of coccidioidomycosis in Ceará State, Northeast Brazil: epidemiologic and diagnostic aspects. Diagn Microbiol Infect Dis. 2010;66:65-72.

7. Cordeiro RA, Fechine MAB, Brilhante RSN, Rocha MFG, Costa AKF, Nagao MATD, et al. Serologic detection of coccidioidomycosis antibodies in northeast Brazil. Mycopathologia. 2009;167:187-90.

8. Cox RA, Magee DM. Coccidioidomycosis: host response and vaccine development. Clin Microbiol Rev. 2004;17:804-39.

9. Cox RA, Britt LA. Isolation and identification of an exoantigen specific for Coccidioides immitis. Infec Immun. 1986;52:138-43.

10. de Macedo RCL, Rosado AS, da Mota FF, Cavalcante MAS, Eulalio KD, Filho AD, et al. Molecular identification of Coccidioides spp. in soil samples from Brazil. BMC Microbiol. 2011;11:180.

11. Deus Filho A. Coccidioidomycosis. J Bras Pneumol. 2009;35:920-30.

12. Fisher MC, Koenig GL, White TJ, Taylor JW. Molecular and phenotypic description of Coccidioides posadasii sp. nov., previously recognized as the non-California population of Coccidioides immitis. Mycologia. 2002;94:73-84.

13. Fujita SI, Senda Y, Nakaguchi S, Hashimoto T. Multiplex PCR using internal transcribed spacer 1 and 2 regions for rapid detection and identification of yeasts strains. J Clin Microbiol. 2001;39:3617-22.

14. Gomes OM, Serrano RRP, Pradel HOV, Moraes NLTB, Varella ALB, Fiorelle AI, et al. Pulmonary coccidioidomycosis. 1st national case. AMB Rev Assoc Med Bras. 1978;24:167-8.

15. Greene DR, Koenig G, Fisher MC, Taylor JW. Soil isolation and molecular identification of Coccidioides immitis. Mycologia. 2000;92:406-10.

16. Gromadzki SG, Chaturverdi V. Limitations of the AccuProbe Coccidioides immitis culture identification test: false-negative results with formaldehyde-killed cultures. J Clin Microbiol. 2000;38:2427-8.

17. Homolka L, Lisá L, Eichlerová I, Valásková V, Baldrian P. Effect of long-term preservation of basidiomycetes on perlite in liquid nitrogen on their growth, morphological, enzymatic and genetic characteristics. Fungal Biol. 2010;114:929-35.

18. Johnson SM, Simmons A, Pappagianis D. Amplification of coccidioidal DNA in clinical specimens by PCR. J Clin Microbiol. 2004;42:1982-5.

19. Koufopanou V, Burt A, Szaro T, Taylor JW. Gene genealogies, cryptic species, and molecular evolution in the human pathogen Coccidioides immitis and relatives (Ascomycota, Onygenales). Mol Biol Evol. 2001;18:1246-58.

20. Lima R, Borba CM. Viability, morphological characteristics and dimorphic ability of fungi preserved by different methods. Rev Iberoam Micol. 2001;18:191-6.

21. Lindsley MD, Hurst ST, Iqbal NJ, Morrison CJ. Rapid identification of dimorphic and yeast-like fungal pathogens using specific DNA probes. J Clin Microbiol. 2001;39:3505-11.

22. Little GN, Gordon MA. Survival of fungus cultures maintained under mineral oil for twelve years. Mycologia. 1967;59:733-6.

23. Martins MA, Araujo EMPA, Kuwakino MH, Heins-Vaccari EM, Del Negro GMB, Vozza Junior JA, et al. Coccidioidomycosis in Brazil. A case report. Rev Inst Med Trop Sao Paulo. 1997;39:299-304. 
CAVALCANTI, S.D.B.; VIDAL, M.S.M.; SOUSA, M.G.T. \& DEL NEGRO, G.M.B. - Viability and molecular authentication of Coccidioides spp. isolates from the Instituto de Medicina Tropical de São Paulo culture collection, Brazil. Rev. Inst. Med. Trop. Sao Paulo, 55(1): 7-11, 2013.

24. McGinnis MR, Padhye AA, Ajello L. Storage of stock cultures of filamentous fungi, yeasts, and some aerobic actinomycetes in sterile distilled water. Appl Microbiol. $1974 ; 28: 218-2$.

25. Nakasone KK, Peterson AW, Jong S. Preservation and distribution of fungal cultures. In: Mueller GM, Bills GF, Foster MS. Biodiversity of fungi, inventory and monitoring methods. Amsterdam: Elsevier Academic Press: 2004. p. 37-47.

26. Paoli P. Biobanking in microbiology: from sample collection to epidemiology, diagnosis and research. FEMS Microbiol Rev. 2005;29:897-910.

27. Saubolle MA, McKellar PP, Sussland D. Epidemiologic, clinical and diagnostic aspects of coccidioidomycosis. J Clin Microbiol. 2007;45:26-30.

28. Smith D, Onions AHS. A comparison of some preservation techniques for fungi. Trans Br Mycol Soc. 1983;81:535-40

29. Spencer JFT, Spencer DM. Maintenance and culture of yeasts. Methods Mol Biol. 1996;53:5-15.

30. Tintelnot K, De Hoog GS, Antweiler E, Losert H, Seibold M, Brandt MA, et al. Taxonomic and diagnostic markers for identification of Coccidioides immitis and Coccidioides posadasii. Med Mycol. 2007;45:385-93.
31. Togashi RH, Aguiar FMB, Ferreira DB, Moura CM, Sales MTM, Rios NX. Pulmonary and extrapulmonary coccidioidomycosis: three cases in an endemic area in the state of Ceará, Brazil. J Bras Pneumol. 2009; 35:275-9.

32. Umeyama T, Sano A, Kamei K, Niimi M, Nishimura K, Uehara Y. Novel approach to designing primers for identification and distinction of the human pathogenic fung Coccidioides immitis and Coccidioides posadasii by PCR amplification. J Clin Microbiol. 2006;44:1859-62.

33. Wanke B, Lazera MS, Monteiro PCF, Lima FC, Leal NJS, Ferreira Filho PL, et at. Investigation of an outbreak of endemic coccidioidomycosis in Brazil's northeastern state of Piauí with a review of the occurrence and distribution of Coccidioides immitis in three other Brazilian states. Mycopathologia. 1999;148:57-67.

34. World Federation for Culture Collection. World Federation for Culture Collection guidelines for the establishment and operation of collection of cultures of microorganisms. Available from: http://www.wfcc.info/guidelines/

Received: 6 January 2012

Accepted: 1 October 2012 